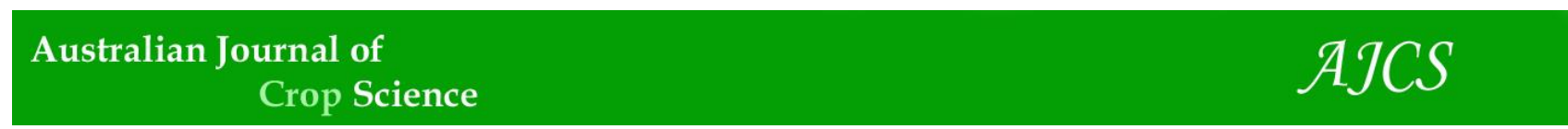

AJCS 11(03):277-283 (2017)

ISSN:1835-2707

doi: 10.21475/ajcs.17.11.03.pne362

\title{
Allelopathic potential of Cymbopogon citratus over beggarticks (Bidens sp.) germination
}

\author{
Fábio Henrique Krenchinski*, Leandro Paiola Albrecht, Alfredo Junior Paiola Albrecht, Patrícia \\ Costa Zonetti, Augusto Tessele, Arthur Arrobas Martins Barroso and Henrique Fabricio Placido
}

\author{
Faculty of Agronomic Sciences, Sao Paulo State University, Botucatu, SP, Brazil
}

*Corresponding author: fhkrenchinski@gmail.com

\begin{abstract}
Allelochemicals are important and innovative tools for weed control as they neither harm the environment nor increase weed management costs. The secondary metabolites can be extracted by water or soaking and later applied in soil or leaves. This study evaluated the leaf extracts of Cymbopogon citratus, affecting germination of Bidens pilosa and B. subalternans seeds. Two trials were conducted in germination chambers. The completely randomized design was employed in both trials with 5 replications. Trial one was arranged in a $2 \times 3$ double factorial design, with two periods of leave collection (morning and afternoon); and three extract preparations (aqueous extract by maceration, aqueous extract by infusion and control with distilled water). Trial two was set up in a $2 \times 2 \times 5$ triple factorial design, with two extracts (aqueous extract by maceration, aqueous extract by infusion); two time of day collection (morning and afternoon) and five extracts concentrations $(0 ; 25 ; 50 ; 75$ and 100\%). The means were compared by $\mathrm{F}$ and Tukey's test $(\mathrm{p} \leq 0.05)$. To evaluate extracts concentrations a regression analysis was run. The results showed that the aqueous extract by maceration of $C$. citratus decreased germination and germination speed of Bidens pilosa and Bidens subalternans more than the aqueous extract by infusion, for both species. The concentrations interfered, inversely and proportionally, decreasing germination and germination speed. The germination of beggarticks was affected by the extracts of $C$. citratus, suggesting further studies for this plant.
\end{abstract}

Keywords: Allelochemicals, Bidens pilosa, Bidens subalternans, Lemon grass, Bioherbicides.

Abbreviations: A_Afternoon; G_Germination; GSI_germination speed index; INF_aqueous extract by infusion; M_Morning; MAC_aqueous extract by maceration.

\section{Introduction}

Among the several weed species that concern farmers, Bidens pilosa (L.) and Bidens subalternans (DC) are the most common weeds in cereals and winter crops. The specie $B$. pilosa, popularly known as hairy-beggarticks, is distributed throughout the Brazilian territory (Kissmann and Groth, 1999). In turn, B. subalternans resembles B. pilosa, differing mainly by the number of awns present in achenes, which are four rather than two to three (Kissmann and Groth, 1999). These plants can affect yield and quality of crops, such as in beans and cotton (Manabe et al., 2015)

A current problem in weed science is herbicide-resistance plants. The acetolactate synthase (ALS) and Acetyl CoA Carboxylase (ACCase), inhibiting herbicides, are considered the most worrisome compounds because they rapidly develop resistant weed plants (Carvalho et al., 2004). Biotypes of $B$. pilosa and $B$. subalternans resistant to ALS inhibiting herbicides have already been found in Brazil (Heap, 2015).

The search for new natural molecules is an alternative to the use of herbicides and pesticides, which can be investigated through allelopathic studies (Nichols et al., 2015). These compounds are derived from the secondary metabolism of plants and can present new modes of action; thereby, generating bio-herbicides which are of great importance for use in agriculture (Bajwa et al., 2015; Duke, 2015). Allelopathic studies have received considerable attention in recent years as new cases of herbicide-resistant weeds increased all over the world (Duke, 2015; Goldfarb et al., 2009).

Allelopathy describes the positive or negative influence of an individual (plant or microorganism) over another through biomolecules defined as allelochemicals produced and released into the environment. These effects are mediated by substances belonging to different categories of compounds, originated from the secondary metabolism, such as terpenoids, steroids, alkaloids, cyanohydrins, long-chain fatty acids, polyacetylenes, unsaturated lactones, tannins, benzoic acid derivatives, phenols, coumarins and flavonoids (Duke, 2015; Nichols et al., 2015). Allelochemicals are water soluble; thus, can be extracted and applied by foliar sprays or in contact with the seed (Bajwa et al., 2015). Secondary metabolites are not produced and found uniformly in the plant, and may be in organs, tissues or specific cellular structures like vacuole, idioblasts and trichomes (Hadacek, 2002).

Lemongrass (Cymbopogon citratus DC.) is a perennial plant forming dense clumps, which can reach up to 1.2 meters high (Prins et al., 2008). These plants contain $0.5 \%$ of its weight composed by essential oil, an important ingredient in weed control (Piccolo et al., 2007). According to Miranda et al. (2013), the quality and quantity of lemongrass essential oil can vary according to the genetic diversity and cultural practices, as well as internal and external factors. During the day, the concentration of active ingredients in plants varies according the time (Gobbo-Neto and Lopes, 2007). 
Given the occurrence of species of Bidens resistant to herbicides and the need for future alternatives for weed control, specifically in the case of $B$. pilosa and $B$. subalternans, there is a demand for studies on new molecules mainly from Brazilian native plants, where the high diversity of flora makes it possible. Therefore, the aim of this study was to evaluate the allelopathic potential of Cymbopogon citratus leaves extracts collected at different times of the day over the germination of B. pilosa and B. subalternans.

\section{Results and Discussion}

First trial - Extracts of Cymbopogon citratus and two collection periods

The interaction between collection period and extracts was not significant; therefore, the factors were analyzed separately, except for the variable $\mathrm{G}$ in the specie Bidens pilosa (Table 1).

\section{Germination and germination speed index of Bidens pilosa}

Once the germination percentage of Bidens pilosa was higher than $85 \%$ in the germination test, the INF and MAC extracts influenced the seed germination. The MAC extract suppressed greatly the seed germination for both periods of leaves collection. The control showed the highest germination values and significantly differed from the other treatments for both collection periods (Table 2).

Both extracts of Cymbopogon citratus were able to cause deleterious effects over the germination of Bidens pilosa, and MAC extract expressed the strongest influence (reducing near $35 \%$ of seed germination). The MAC extract collection periods ( $\mathrm{M}$ and $\mathrm{A}$ ) influenced the germination percentage, in which the morning collection caused more damage to the germination than the afternoon collection. The germination speed index for $B$. pilos $a$ was not affected by the periods of collection. However, for both collection periods, the control extract exhibited the highest GSI values, differing from the other treatments. Once again, the MAC extract displayed the best results, holding back the GSI of this specie and differing statistically from the INF extract and the control (Table 2).

Several authors have claimed that the essential oil of $C$. citratus decreases root length in lettuce (Alves et al., 2004), and the germination of weed seeds, such as Amaranthus blitoides, Amaranthus palmeri, Euphorbia hirta L., Sinaps nigra, Trifolium campestri, Lycopersicum esculentum L. and Triticum aesto (Dudai et al., 1999). Fortes et al. (2009) noticed that $C$. citratus extract did not influence the germination and germination speed in soybean, but caused adverse effects on $B$. pilosa. In accordance to Souza et al. (1998), lemongrass extracts stimulated the root development in cotton (Gossypium hirsutum L.) and corn (Zea mays L.) and inhibited the development of purslane (Portulaca oleracea L.) and beggarticks (Bidens pilosa L.), which may indicate the exudate selectivity and potential future uses.

\section{Germination and germination speed index of Bidens subalternans}

For Bidens subalternans, the collection periods had no influence on G and GSI. The control and INF showed similar result regarding the germination (Table 3). The MAC extract suppressed seed germination for both G and GSI and was significantly different to INF and $\mathrm{C}$, in both collection periods ( $\mathrm{M}$ and $\mathrm{A}$ ). The results point out the potential of $C$. citratus MAC extracts to reduce the germination of $B$. subalternans and B. pilosa seeds.

The collection periods had reduced effects on G and GSI for both Bidens species, which may be due to the similarity in the concentration of essential oils of lemongrass between the two collection times (Miranda et al., 2013; Do Nascimento et al., 2006). According to Miranda et al. (2013), in Cymbopogon citratus, the collection should be avoided at noon times, because there is a reduction in the essential oil content.

The superiority of the possible allelopathic effects of MAC in comparison to INF should be explained by the extraction method, where using tissue fragmentation is more efficient, since the secondary metabolites may be in certain organs, tissues or specific cellular structures (Hadacek, 2002). Another important characteristic that could have affected the INF performance was the extraction temperature. A study conducted by Martins et al. (2002) reported that the drying temperature of $60^{\circ} \mathrm{C}$ decreased the volume of essential oil in C. citratus by $21 \%$, when compared to extraction from fresh plant. According to the same author, the citral content decreased 3.5 and $12 \%$ with drying temperatures of 50 and $60^{\circ} \mathrm{C}$, respectively.

The essential oils of $C$. citratus is primarily composed of monoterpenes, in which the essential components are geranial (43\%) and neral $(31 \%)$, which together form the citral (Oliveira et al., 2011). The terpenes present in the essential citral oil are isopentenyl diphosphate and its isomer dimethyl diphosphate both are produced at two sites. In the cytoplasm, they are produced via mevalonate (MVA) dependent pathway and in plastids produced in the metabolic pathway of methylerythritol 4-phosphate (MEP) (Nagegowda, 2010). Studies have shown that $C$. citratus has antidepressant, antiseptic, astringent, bactericidal, fungicidal activities and sedative properties (Naik et al., 2010).

\section{Second trial - Extracts concentrations of Cymbopogon citratus and two collection periods}

The interaction among the factors such as collecting of extracts and concentrations was significant for the studied variables. So, the factors were analyzed with triple interaction, in both species (Table 4).

\section{Germination and germination speed index of Bidens pilosa} and Bidens subalternans

Regarding the germination percentage $(\mathrm{G})$ in the morning period, MAC extract caused lower germination of $B$. pilosa with the 25,75 and $100 \%$ concentration compared to INF. In the afternoon period collection, MAC was superior once again, reducing seeds germination at concentrations 25 and $100 \%$. The collection period influenced the germination percentage only in concentrations of 25 and $50 \%$, in which the morning collection had greater germination suppression in both extracts (Table 5).

The morning collection period presented higher concentration of secondary metabolites than the afternoon one, as the concentrations of such metabolites may fluctuate during the day (Gonçalves et al., 2009; Miranda et al., 2013; Do Nascimento et al., 2006).

For Bidens pilosa, GSI in the morning was higher in INF compared to MAC, only in the concentration of $25 \%$. In the afternoon, INF was superior to MAC in the concentration of $50 \%$. The morning collection period resulted in lower GSI compared to INF in the MAC extract. For the INF extract, this 
Table 1. ANOVA summary variables G and GSI of the two species of Bidens, in a $2 \times 3$ factorial design double, being the two collection periods and three ways of preparing extracts.

\begin{tabular}{lllll}
\hline & \multicolumn{2}{l}{ Bidens pilosa } & \multicolumn{2}{l}{ Bidens subalternans } \\
\hline & Pr $>$ F (probability of a greater F value) \\
\hline F.V & G & GSI & G & GSI \\
\hline Collec. & 0.328 & 0.891 & 0.440 & 0.835 \\
Ext. & 0.000 & 0.000 & 0.000 & 0,000 \\
Collec.* Ext. & 0.039 & 0.416 & 0.649 & 0,402 \\
\hline
\end{tabular}

F.V - variation factors; Collec. - Hour collection (Morning and Afternoon); Ext. - Extracts (maceration extract, infusion extract and control); G (germination percentage) and GSI (germination speed index).

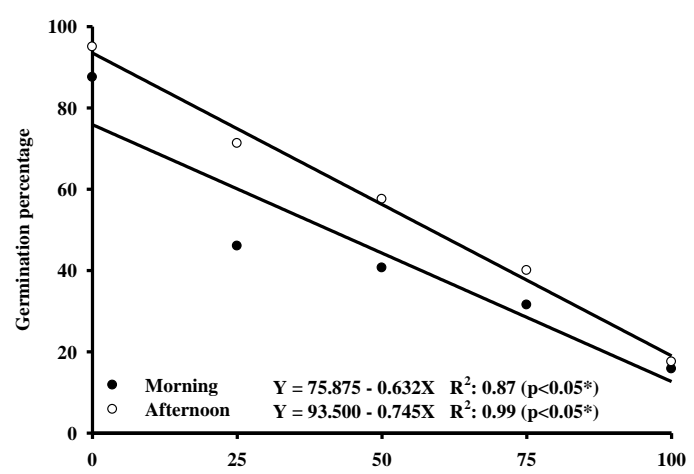

A

Concentrations (\%)
B

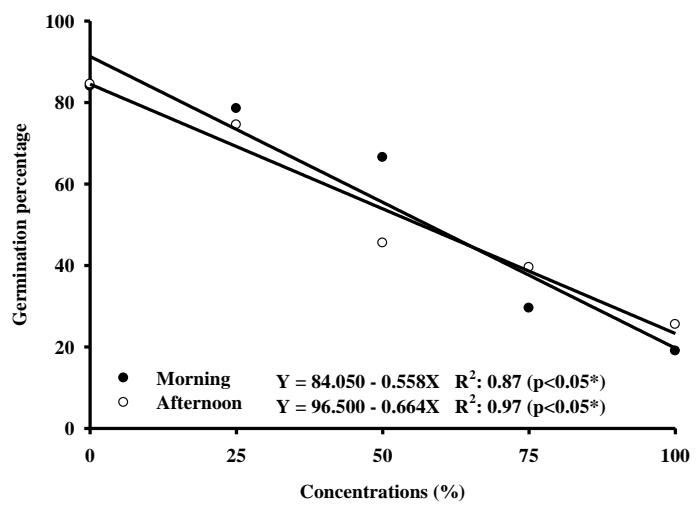

Fig 1. Linear regression of Cymbopogon citratus aqueous and infusion extracts (MAC, A); (INF, B) effects at different concentrations $(0,25,50,75$ and $100 \%)$ in Bidens pilosa seed germination percentage, during two times of plant harvest (morning and afternoon).* significant $(\mathrm{p} \leq 0.05)$.

Table 2. Mean values of germination percentage and germination speed index of Bidens pilosa seeds undergoing treatment with aqueous extracts of Cymbopogon citratus, collected at different times of the day compared to the control without extracts.

\begin{tabular}{|c|c|c|c|c|c|c|}
\hline \multicolumn{7}{|c|}{ Bidens pilosa } \\
\hline & $\mathrm{G}(\%)$ & & & GSI & & \\
\hline Treatments & M & A & Mean & $\mathrm{M}$ & $\mathrm{A}$ & Mean \\
\hline MAC & $32.50 \mathrm{Bc}$ & $41.25 \mathrm{Ac}$ & 36.87 & $2.77 \mathrm{Ac}$ & $3.32 \mathrm{Ac}$ & 3.04 \\
\hline INF & $60.00 \mathrm{Ab}$ & $55.62 \mathrm{Ab}$ & 57.81 & $6.53 \mathrm{Ab}$ & $6.01 \mathrm{Ab}$ & 6.27 \\
\hline $\mathrm{C}$ & $83.75 \mathrm{Aa}$ & $86.25 \mathrm{Aa}$ & 85.00 & $15.00 \mathrm{Aa}$ & 15.10Aa & 15.05 \\
\hline Mean & 58.75 & 61.04 & & 8.10 & 8.14 & \\
\hline $\mathrm{CV} \%$ & 9.32 & & & 9.74 & & \\
\hline
\end{tabular}

* Mean values followed by different uppercase letters in the same row ( $\mathrm{p} \leq 0.05$ by F-test) and lowercase letters in the same column ( $\mathrm{p} \leq 0.05$ by $\mathrm{F}$-test) are significantly different. MAC (maceration extract), INF (infusion extract); C (control); M (morning); A (afternoon); G (germination percentage) and GSI (germination speed index).

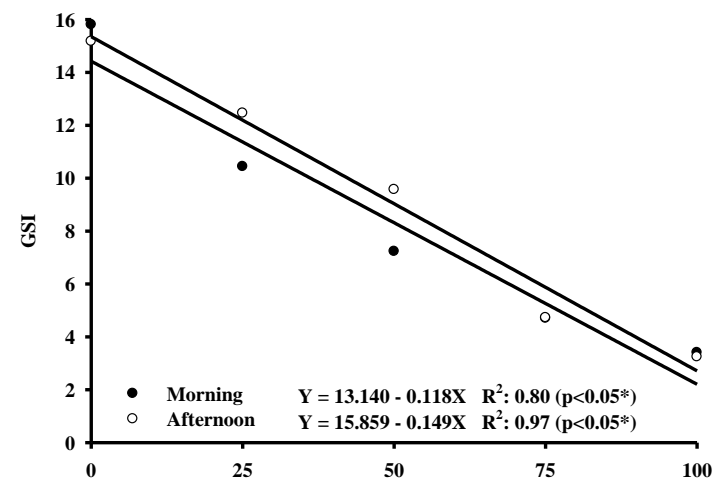

A

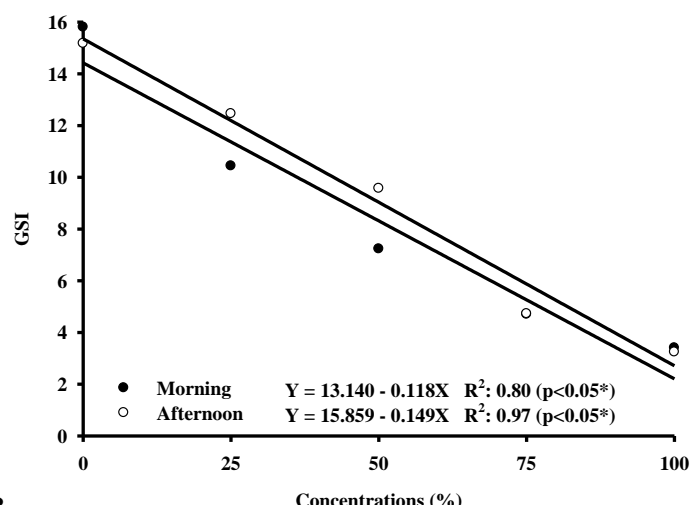

B

Fig 2. Linear regression of Cymbopogon citratus aqueous and infusion extracts (MAC, A); (INF, B) effects at different concentrations $(0,25,50,75$ and 100\%) in Bidens pilosa germination seed index, during two times of plant harvest (morning and afternoon).* significant $(\mathrm{p} \leq 0.05)$. 
Table 3. Mean values of germination percentage and germination speed index of Bidens subalternans seeds undergoing treatment with aqueous extracts of Cymbopogon citratus, collected at different times of the day compared to the control without the use of extracts.

\begin{tabular}{lllllll}
\hline \multicolumn{7}{c}{ Bidens subalternans } \\
\hline Treatments & $\mathrm{M}$ & $\mathrm{A}$ & Mean & $\mathrm{M}$ & $\mathrm{A}$ & Mean \\
\hline MAC & $14.50 \mathrm{Ab}$ & $16.00 \mathrm{Ab}$ & 15.25 & $0.83 \mathrm{Ab}$ & $1.43 \mathrm{Ab}$ & 1.13 \\
INF & $47.00 \mathrm{Aa}$ & $43.50 \mathrm{Aa}$ & 45.25 & $6.13 \mathrm{Aa}$ & $6.80 \mathrm{Aa}$ & 6.47 \\
$\mathrm{C}$ & $56.50 \mathrm{Aa}$ & $51.50 \mathrm{Aa}$ & 54.00 & $10.02 \mathrm{Aa}$ & $11.81 \mathrm{Aa}$ & 10.92 \\
\hline Mean & 39.33 & 37.00 & & 6.26 & 6,08 \\
\hline CV \% & 18.97 & & & 32.69 & &
\end{tabular}

* Mean values followed by different uppercase letters in the same row ( $\mathrm{p} \leq 0.05$ by F-test) and lowercase letters in the same column ( $\mathrm{p} \leq 0.05$ by $\mathrm{F}$-test) are $\mathrm{significantly}$ different. MAC (maceration extract), INF (infusion extract); C (control); M (morning); A (afternoon); G (germination percentage) and GSI (germination speed index).

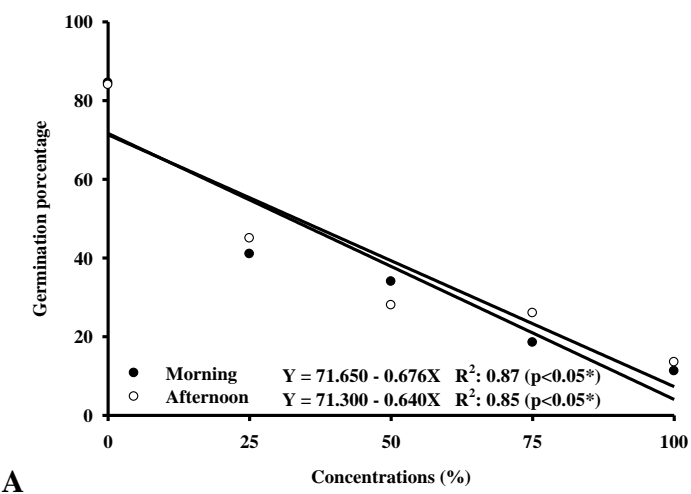

A

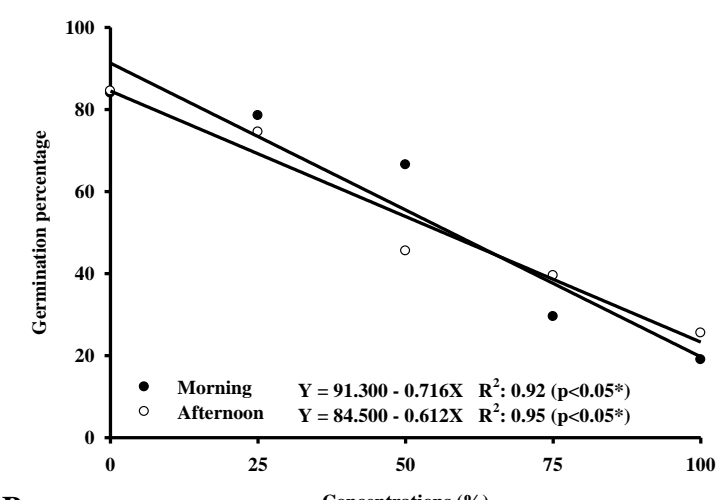

B

Concentrations $(\%)$

Fig 3. Linear regression of Cymbopogon citratus aqueous and infusion extracts (MAC, A); (INF, B) effects at different concentrations $(0,25,50,75$ and $100 \%)$ in Bidens subalternans seed germination percentage, during two times of plant harvest (morning and afternoon).* significant $(\mathrm{p} \leq 0.05)$.

Table 4. ANOVA summary variables G and GSI of the two species of Bidens, in a 2x2x5 triple factorial design, with two extracts, two times of collections, applied in five concentrations.

\begin{tabular}{lllll}
\hline & \multicolumn{2}{l}{ Bidens pilosa } & \multicolumn{2}{l}{ Bidens subalternans } \\
\hline F.V & Pr $>$ F (probability of a greater F value) & \\
\hline Collec. & G & GSI & G & GSI \\
Ext. & 0.000 & 0.000 & 0.941 & 0.086 \\
Conc. & 0.000 & 0.000 & 0.000 & 0.000 \\
Collec.* Ext. & 0.000 & 0.000 & 0.000 & 0.000 \\
Ext.* Conc. & 0.065 & 0.335 & 0.141 & 0.355 \\
Conc.*Collec. & 0.016 & 0.000 & 0.000 & 0.000 \\
Conc.*Collec.* Ext. & 0.000 & 0.000 & 0.000 & 0.000 \\
\hline
\end{tabular}

F.V - variation factors; Collec. - Hour collection (Morning and Afternoon); Ext. - Extracts (maceration extract, infusion extract and control); Conc. - Concentrations (0, 25, $50,75$ and $100 \%) \mathrm{G}$ (germination percentage) and GSI (germination speed index).

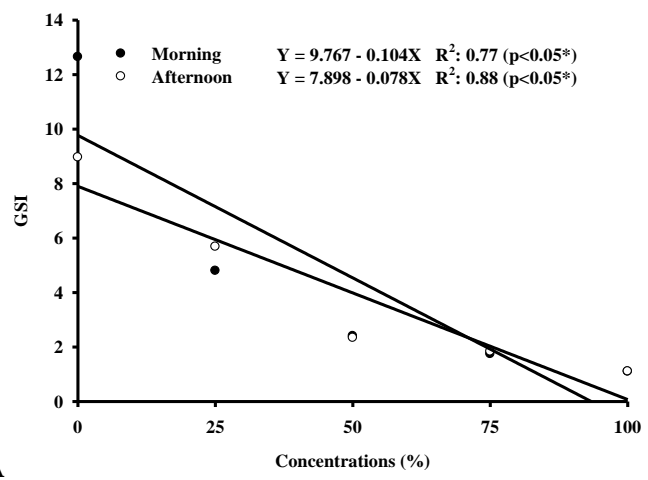

A

Fig 4. Linear regression of Cymbopogon citratus aqueous and infusion extracts (MAC, A); (INF, B) effects at different concentrations $(0,25,50,75$ and $100 \%)$ in Bidens subalternans germination seed index, during two times of plant harvest (morning and afternoon).* significant $(\mathrm{p} \leq 0.05)$. 
Table 5. Mean values of germination and germination speed index of Bidens pilosa seeds undergoing treatment with different concentrations of extracts of Cymbopogon citratus (crude aqueous and infusion), collected at different times of the day.

\begin{tabular}{|c|c|c|c|c|c|c|c|c|}
\hline & \multicolumn{4}{|c|}{ MAC } & \multicolumn{4}{|c|}{ INF } \\
\hline & $\mathrm{G}(\%)$ & & GSI & & $\mathrm{G}(\%)$ & & GSI & \\
\hline Concentrations (\%) & $\mathrm{M}$ & $\mathrm{A}$ & $\mathrm{M}$ & A & $\mathrm{M}$ & A & M & A \\
\hline 0 & $87.50 \mathrm{Aa}^{*}$ & $95.00 \mathrm{Aa}$ & $15.80 \mathrm{Aa}$ & $16.81 \mathrm{Aa}$ & $94.50 \mathrm{Aa}$ & $94.00 \mathrm{Aa}$ & $15.98 \mathrm{Aa}$ & $15.17 \mathrm{Aa}$ \\
\hline 25 & $46.00 \mathrm{Bb}$ & $71.25 \mathrm{Ba}$ & $7.05 \mathrm{Bb}$ & $11.75 \mathrm{Aa}$ & $60.62 \mathrm{Ab}$ & $83.50 \mathrm{Aa}$ & $10.44 \mathrm{Ab}$ & $12.45 \mathrm{Aa}$ \\
\hline 50 & $40.62 \mathrm{Ab}$ & $57.50 \mathrm{Aa}$ & 5.88Aa & $7.26 \mathrm{Ba}$ & $48.00 \mathrm{Ab}$ & $66.00 \mathrm{Aa}$ & $7.22 \mathrm{Ab}$ & $9.57 \mathrm{Aa}$ \\
\hline 75 & $31.50 \mathrm{Ba}$ & $40.00 \mathrm{Aa}$ & 4.97Aa & 4.13Aa & 45.00Aa & $40.50 \mathrm{Aa}$ & $4.70 \mathrm{Aa}$ & $4.72 \mathrm{Aa}$ \\
\hline 100 & $15.75 \mathrm{Ba}$ & $17.50 \mathrm{Ba}$ & $2.26 \mathrm{Aa}$ & $1.91 \mathrm{Aa}$ & $32.50 \mathrm{Aa}$ & $32.50 \mathrm{Aa}$ & $3.40 \mathrm{Aa}$ & $3.24 \mathrm{Aa}$ \\
\hline Mean & $50.26 \mathrm{~B}$ & & $7.77 \mathrm{~B}$ & & $59.71 \mathrm{~A}$ & & $8.70 \mathrm{~A}$ & \\
\hline $\mathrm{CV} \%$ & 14.30 & & 16.31 & & 14.30 & & 16.31 & \\
\hline
\end{tabular}

Table 6. Mean values of germination and germination speed index of Bidens subalternans seeds undergoing treatment with different concentrations of extracts of Cymbopogon citratus (crude aqueous and infusion), collected at different times of the day.

\begin{tabular}{|c|c|c|c|c|c|c|c|c|}
\hline & \multicolumn{4}{|c|}{ MAC } & \multicolumn{4}{|c|}{ INF } \\
\hline & $\mathrm{G}(\%)$ & & GSI & & $\mathrm{G}(\%)$ & & GSI & \\
\hline Concentrations (\%) & $\mathrm{M}$ & A & $\mathrm{M}$ & $\mathrm{A}$ & $\mathrm{M}$ & $\mathrm{A}$ & $\mathrm{M}$ & $\mathrm{A}$ \\
\hline 0 & $84.00 \mathrm{Aa}^{*}$ & $84.10 \mathrm{Aa}$ & $12.64 \mathrm{Aa}$ & $9.96 \mathrm{Aa}$ & $84.50 \mathrm{Aa}$ & $84.55 \mathrm{Aa}$ & $11.78 \mathrm{Aa}$ & $11.61 \mathrm{Aa}$ \\
\hline 25 & $41.00 \mathrm{Ba}$ & $45.00 \mathrm{Ba}$ & $4.79 \mathrm{Ba}$ & $5.68 \mathrm{Ba}$ & $78.50 \mathrm{Aa}$ & $74.50 \mathrm{Aa}$ & $10.79 \mathrm{Aa}$ & $9.84 \mathrm{Aa}$ \\
\hline 50 & $34.00 \mathrm{Ba}$ & $28.00 \mathrm{Ba}$ & $2.40 \mathrm{Ba}$ & $2.33 \mathrm{Ba}$ & $56.50 \mathrm{Aa}$ & $45.50 \mathrm{Aa}$ & 8.40Aa & $6.49 \mathrm{Aa}$ \\
\hline 75 & $18.50 \mathrm{Aa}$ & $26.00 \mathrm{Ba}$ & $1.74 \mathrm{Ba}$ & $1.83 \mathrm{Ba}$ & $29.50 \mathrm{Aa}$ & $39.50 \mathrm{Aa}$ & 3.69Aa & $5.04 \mathrm{Aa}$ \\
\hline 100 & $11.25 \mathrm{Aa}$ & $13.50 \mathrm{Aa}$ & $1.09 \mathrm{Aa}$ & $1.10 \mathrm{Ba}$ & $19.00 \mathrm{Aa}$ & $25.50 \mathrm{Aa}$ & $2.49 \mathrm{Aa}$ & $3.33 \mathrm{Aa}$ \\
\hline Mean & $38.57 \mathrm{~B}$ & & $4.26 \mathrm{~B}$ & & $54.70 \mathrm{~A}$ & & $7.35 \mathrm{~A}$ & \\
\hline CV\% & 18.61 & & 23.58 & & 18.61 & & 23.58 & \\
\hline
\end{tabular}

* Mean values followed by different uppercase letters in the same row, between extracts (MAC and INF), within each collection period and concentrations; different lowercase letters in the same row, between collection periods ( $\mathrm{M}$ and $\mathrm{A}$ ) and within each extract and concentration, are signif ic antly different from each other ( $\mathrm{p} \leq 0.05$ ), by F-test. MAC (maceration extract); INF (infusion extract); C (control); M (morning); A (afternoon), G (germination percentage) a nd GSI (germination speed index)

was observed at a concentration of 25 to $50 \%$ (Table 5). In turn, for B. subalternans, the morning MAC extract reduced the germination at the concentrations of 25 and $50 \%$ compared to INF. The afternoon MAC extract decreased germination of $B$. subalternans at the concentrations 25,50 and $75 \%$, compared to INF, similarly to B. pilosa. The germination speed index was higher in the afternoon for INF at concentrations 25, 50 and $75 \%$, compared to MAC. The same was true for the morning collection period (Table 6).

\section{Extracts concentrations}

The concentration assessment allowed fitting a significant linear regression for all variables. For B. pilosa, MAC promoted reductions of $0.63 \%$ and $0.74 \%$ in seed germination with the increase of $1 \%$ in the extract concentration for the morning and afternoon collection period, respectively (Fig. 1A). We observed reductions of 63.2 and $74.5 \%$ at the concentration of $100 \%$, compared to control, for collections in the morning and afternoon, respectively. For INF (Fig. 1B), the reduction was of 0.55 and 0.66 with an increase of $1 \%$ in the extract concentration, for collections in the morning and afternoon, respectively. Reductions in germination by 56 and $66.4 \%$ were found with the concentration of $100 \%$ compared to control (concentration 0) for the collections in the morning and afternoon, respectively. The MAC provided greater potential to decrease germination in both collection periods and $B$. subalternans was less affected by the extracts. Fortes et al. (2009) achieved similar results using hot aqueous extract concentrations of $C$. citratus over the germination of $B$. pilosa. Results for the germination speed were similar to the germination percentage, for the MAC extract (Fig. 2A): every increase in the concentration of this extract reduced the germination speed by 0.12 and 0.15 , for collections in the morning and afternoon, respectively. As for the INF extract, the germination speed decreased by 0.12 for collections in both periods ( $\mathrm{M}$ and $\mathrm{A}$ ). The weed emergence speed ensures a prior interference with the crop by competing for water, light and nutrients, and produces seeds before the end of the crop cycle. According to Souza et al. (1998), lemongrass extracts stimulated the development of roots in cotton (Gossypium hirsutum L.) and corn (Zea mays L.) and inhibited the development of purslane (Portulaca oleracea L.) and beggarticks (Bidens pilosa L.), which demonstrates the potential use of these extracts as selective pre-emergent bio-herbicide in commercial crops, or even in the identification of a new molecule with herbicide potential.

Regarding B. subalternans, germination percentage (Fig. $3 \mathrm{AB}$ ) was also inhibited with increasing concentrations of the extracts. For MAC and INF (Fig. 3AB), the largest decrease in germination was caused by $100 \%$ concentration in the morning, which provided a reduction of $67.6 \%$ and $71.6 \%$ over control, respectively. In relation to the slope, it was verified that for the MAC extract, there was a reduction in germination by 0.68 and 0.64 to each percentage increase of the extract concentration in the morning and afternoon, respectively (Fig. 3A). For INF, there was a decline of 0.72 and 0.62 in the germination percentage for collections in the morning and afternoon, respectively (Fig. 3B).

The germination speed index was also negatively affected by increasing concentrations. For MAC, there was a decrease in germination speed in the order of 0.10 and 0.08 for every percentage increase in the extract concentration in the collections in the morning and afternoon, respectively (Fig. 4A). For INF, the collection in the morning provided a reduction of 0.10 to each percentage increase in the extract 
concentration. For INF extract, this reduction was of 0.08 (Fig. 4B).

In general, the two variables were reduced by increasing concentrations of $C$. citratus leaves extracts in both species of Bidens. However, there was no complete inhibition of germination or germination speed index after application of $100 \%$ extract concentration. This potential allelopathic effect may be related to substances found in the essential oil of $C$. citratus, including the alpha-citral (geranial) and beta-citral (neral), which corresponds to 70 to $85 \%$ its volume. These substances are acyclic monoterpenoid aldehyde, solely denominated citral (Guimarães et al., 2008). In addition, myrcene can be related to these events (12 to $20 \%$ of oil volume) (Guimarães et al., 2008).

The ability to influence the germination of seeds can be related to the decreased activity of $\alpha$-amylase, responsible for breaking down starch and releasing many oligosaccharides that are remobilized for growth of the embryonic axis. The essential oil of $C$. citratus can present herbicidal effect due to the ability to reduce the $\alpha$-amylase activity; thereby, reducing seed germination (Poonpaiboonpipat et al., 2013).

Alves et al., (2004), evaluated the effect of essential oil of C. citratus on seed germination and root length of lettuce and found that the concentration of 0.100 and $1 \%$ resulted in a total reduction of these variables. According to Dudai et al. (1999), C. citratus extract inhibited the germination of Amaranthus blitoides, Amaranthus palmeri, Euphorbia hirta L., Sinaps nigra, Trifolium campestri, Lycopersicum esculentum L. and Triticum aestivum when applied at 20-80 ppm, varying with the soil employed in the experiment. Germination tests are important tools to identify plants with allelopathic potential, because they are simple to interpret (Souza et al., 2007), subsiding new strategies to advance in studies based on allelopathy. As verified by Alves et al. (2004); Dubai et al. (1999); Fortes et al. (2009); Souza et al. (1998), extract of $C$. citratus is a potential bioherbicide with pre-emergence activity, once it has the ability to decrease the germination of weeds.

\section{Materials and Methods}

\section{First trial - Extracts of Cymbopogon citratus and two} collection periods

This trial took place at Federal University of Paraná, Palotina Sector. The experiment was carried out in a BOD germination chamber, at a constant temperature of $25^{\circ} \mathrm{C}$ and 12 hours of light (3,800 lux), with daily evaluations during 26 days after sowing. The experiment was arranged in a completely randomized design, with five replications in a $2 \times 3$ double factorial design. The factor one was the two collection periods, 7:30h am (M) and 4:00h pm (A); and factor two consisted of three ways of preparing extracts: aqueous extract by maceration (MAC), aqueous extract by infusion (INF) and control with distilled water (C). Data was analyzed according to Pimentel-Gomes and Garcia (2002), subjected to variance analysis, and whenever significant, compared by Tukey test $(\mathrm{p} \leq 0.05)$. The F-test was considered conclusive for the collection periods.

\section{Second trial - Extracts concentrations of Cymbopogon citratus and two collection periods}

The trial was carried out at same laboratory in a BOD germination chamber at a constant temperature of $25^{\circ} \mathrm{C}$ and 12 hours of light a day (3,800 lux). The experiment was evaluated daily for 26 days to determinate the effects of concentration and extract in two collection periods.

The completely randomized design was employed, with five replications in a $2 \times 2 \times 5$ triple factorial design, with two extracts, MAC and INF; two times of collections, 7:30h am (M) and 4:00h pm (A); and five concentrations: 0, 25, 50, 75 and $100 \%$ crude extract, in which the concentration of $0 \%$ consisted of distilled water (as C).

Data were analyzed according to trial one. All the necessary breakdowns were made and the F-test was considered conclusive for the extracts and collection periods. We ran regression analysis $(\mathrm{p} \leq 0.05)$ for concentration variable.

\section{Plant materials}

In both experiments, the extracts were tested for Bidens pilosa and Bidens subalternans. The seeds of both species were collected in farms, dried in shade and stored in a cool and dry place until trials. Prior to the experiment, germination tests were undertaken in order to assess their quality. The leaves of Cymbopogon citratus were collected to prepare the extracts.

\section{Extracts preparation and conduction}

Leaves of Cymbopogon citratus were collected in the morning and afternoon, selecting only non-damaged or senescent leaves. In MAC, leaves were ground separately in a blender with distilled water for 2 minutes at a proportion of one part of fresh weight of the leaf to five parts of distilled water (1:5). The extract was filtered through cheesecloth and stored in amber vials under refrigeration at $12^{\circ} \mathrm{C}$.

For the preparation of the extract by infusion (INF), leaves were chopped and immersed in distilled water at $100^{\circ} \mathrm{C}$. They were set to rest until cooling and then filtered through cheesecloth and stored in amber vials under refrigeration at $12^{\circ} \mathrm{C}$.

For both trials, 50 seeds of $B$. pilosa and B. subalternans were sown in transparent plastic boxes, Gerbox type $(0.11 \mathrm{x}$ $0.11 \times 0.03 \mathrm{~m})$. All gerboxes were lined with filter paper (germitest), moistened with seven $\mathrm{mL}$ of extract, each corresponding to its treatment, and completed with three $\mathrm{mL}$ every seven days with its respective treatment concentration.

\section{Data gathering}

Analyses were made for percentage germination (G) and germination speed index (GSI). In both experiments, seeds with root length equal or higher than $2 \mathrm{~mm}$ were considered germinated. The germination speed index (GSI) was determined according to Ferreira and Borghetti (2008), by the formula: GSI $=\mathrm{G} 1 / \mathrm{N} 1+\mathrm{G} 2 / \mathrm{N} 2+\ldots \mathrm{Gn} / \mathrm{Nn}$. Where: $\mathrm{G} 1$, $\mathrm{G} 2 \ldots \mathrm{Gn}=$ number of seeds or seedlings germinated on the day of observation and $\mathrm{N} 1, \mathrm{~N} 2+\ldots+\mathrm{Nn}=$ number of days (hours) after sowing.

\section{Conclusion}

Aqueous extract by maceration of $C$. citratus leaves has greater effect in reducing the germination and germination speed of the genus Bidens compared to aqueous extract by infusion. The concentrations of the extracts interfere, inversely and proportionally, with the germination and germination speed. The collection periods had minor effects over the results. B. pilosa and B. subalternans are susceptible 
to $C$. citratus extracts, indicating its allelopathy potential for these weed species.

\section{References}

Alves MCS, Filho SM, Innecco R (2004) Alelopatia de extratos voláteis na germinação de sementes e no comprimento da raiz de alface. Pesqui Agropec Bras. 39: 1083-1086.

Bajwa AA, Mahajan G, Chauhan BS. (2015) Nonconventional weed management strategies for modern agriculture. Weed Sci. 63:723-747.

Carvalho SJP, López-Ovejero RF, Moysés TC, Chamma HMCP, Christoffolete PJ (2004) Identificação de biótipos de Bidens spp. resistentes aos inibidores da ALS através de teste germinativo. Planta Daninha. 22:411-417.

Do Nascimento IB, Innecco R, Matos SH, Borges NSS, Marco CA. (2006). Influência do horário de corte na produção de óleo essencial de capim-santo (Andropogum sp). Rev Caatinga. 19:123-127.

Dudai N, Poljakoff-Mayber A, Mayer AM, Putievsky E, Lerner HR (1999) Essential oils as allelochemicals and their potential use as bioherbicides. J Chem Ecol. 25:10791089.

Duke SO (2015) Proving allelopathy in crop-weed interactions. Weed Sci. 63:121-132.

Ferreira AG, Borguetti F. (2008) Germinação: do básico ao aplicado, 3rd ed. Artmed, Porto Alegre. 323.

Ferreira DF (2011) Sisvar: a computer statistical analysis system. C Agrotec. 35:1039-1042.

Fortes AMT, Mauli MM, Rosa DM, Piccolo G, Marques DSM, Refosco RMC (2009) Efeito alelopático de sabugueiro e capim-limão na germinação de picão-preto e soja. Acta Sci Agron. 31:241-246.

Gobbo-Neto L, Lopes NP (2007) Plantas medicinais: fatores de influência no conteúdo de metabólitos secundários. Quím Nova. 30:374, 2007.

Goldfarb M, Pimentel LW, Pimentel NW (2009) Alelopatia: relações nos agroecossistemas. Tec Ciên Agropec. 3:23-28.

Gonçalves GG, Mancinelli RC, Morais LAS (2009) Influência do horário de corte no rendimento de óleo essencial de alfavaquinha e alecrim. Hortic Bras. 27:108112.

Guimarães LGDL, Cardoso MDG, Zacaroni LM, Lima RKD, Pimentel FA, Morais A.R.D. (2008). Influence of light and temperature on the oxidation of the essential oil of lemongrass (Cymbopogon citratus (DC) Stapf). Quím Nova. 31:1476-1480.

Hadacek, F (2002) Secondary metabolites as plant traits: current assessment and future perspectives. Crit Rev Plant Sci. 21:273-322.

Heap I (2015) The international survey of herbicide resistant weeds. http://www.weedscience.org. Accessed: 20 november, 2015.

Kissmann CG, Groth D (1999) Plantas infestantes e nocivas, 2th edn. Basf, São Paulo. 798.

Manabe PMS, Matos CC, Ferreira EA, Silva AF, Silva AA, Sediyama T, Manabe A, Rocha PRR, Silva CT (2015) Efeito da competição de plantas daninhas na cultura do feijoeiro. Biosci J. 31:333-343.

Martins PM, Melo EC, Barbosa LCAB, Santos RHS, Machado MC (2002) Influência da temperatura e velocidade do ar de secagem no teor e composição química do óleo essencial de capim-limão. Acta Hort. 569:155-160.
Miranda VC, Leal TCAB, Cardoso DP, Santos VM (2013) Evaluation of the effect of time of cutting on the content of the essential oil of the holy grass (Cymbopogon citratus (DC) Stapf). J Biotech and Biodiver. 4:55-59.

Nagegowda DA (2010) Plant volatile terpenoid metabolism: biosynthetic genes, transcriptional regulation and subcellular compartmentation. FEBS letters. 584:29652973.

Naik MI, Fomda BA, Jaykumar E, Bhat JA (2010) Antibacterial activity of lemongrass (Cymbopogon citratus) oil against some selected pathogenic bacterias. Asian Pacif J Trop Medicine. 3: 535-538.

Nichol, V, Verhulst N, Cox R, Govaerts B. (2015). Weed dynamics and conservation agriculture principles: A review. Field Crop Res. 183: 56-68.

Oliveira MMM, Brugnera DF, Cardoso MG, Guimarães LGL. Piccoli, RH (2011) Rendimento, composição química e atividade antilisterial de óleos essenciais de espécies de Cymbopogon. Rer Bras Plant Medic. 13:8-16.

Piccolo G, Rosa DM, Marques DS, Mauli MM, Fortes AMT (2007) Efeito alelopático de capim limão e sabugueiro sobre a germinação de guanxuma. Semina Ciênc Agrá. 28:381-386.

Pimentel-Gomes F, Garcia CH (2002) Estatística aplicada a experimentos agronômicos e florestais: exposição com exemplos e orientações para uso de aplicativos. 1th edn. Fealq, Piracicaba. 309.

Poonpaiboonpipat T, Pangnakorn U, Suvunnamek U, Teerarak M, Charoenying P, Laosinwattana C (2013) Phytotoxic effects of essential oil from Cymbopogon citratus and its physiological mechanisms on barnyardgrass (Echinochloa crus-galli). Ind Crop Produc. 41:403-407.

Prins, C. L., de Paiva Freitas, S., Campostrini, E., de Amaral Gravina, G., \& de Oliveira Reis, F. (2008). Efeito do confinamento do sistema radicular sobre capim-limão (Cymbopogon citratus). Rev Ciênc Agron. 39:416-421.

Souza CSM, da Silva WLP, de Moura Guerra AMN, Cardoso MCR, Torres SB (2007) Alelopatia do extrato aquoso de folhas de aroeira na germinação de sementes de alface. Rev Verde. 2:96-100

Souza L, Cruz MES, Constantin J (1998) Efeitos alelopáticos de espécies vegetais medicinais sobre espécies silvestres e cultivadas. Paper presented at the 2 th reunião anual de microbiologia agrícola e plantas medicinais, Universidade Estadual de Maringá, Brazil, 25-29 July 1998. 